\title{
Optimal Configuration in Production Planning and Control
}

\section{Findings of a Simulation-based Evaluation Study}

\author{
Christoph Wolfsgruber and Gerald Lichtenegger \\ Institut für Maschinenbau- und Betriebsinformatik, Technische Universität Graz, Graz, Austria
}

Received March 1, 2016; accepted March 30, 2016; published online June 2, 2016

\begin{abstract}
The operational practice is undergoing fundamental changes due to the increasing complexity and new technological possibilities often summarized with the buzzword 'Industrie 4.0'. Besides others, these trends will have major impacts on the way production is planned. This paper shows findings of a simulation-based evaluation of production planning and control methods regarding these challenges. Based on these fundamental insights, a framework for an optimal configuration in production planning and control is presented.
\end{abstract}

Keywords: Production planning, Production control, Push systems, Pull systems, Discrete event simulation, Industry 4.0

Optimale Konfiguration in der Produktionsplanung und -steuerung-Erkenntnisse aus einer simulationsbasierten Evaluierungsstudie

Zusammenfassung: Die betriebliche Praxis erfährt zurzeit grundlegende Veränderungen aufgrund der zunehmenden Komplexität und neuen technischen Möglichkeiten - oft unter dem Schlagwort "Industrie 4.0" zusammengefasst. Diese Trends werden unter Anderem erhebliche Auswirkungen auf die Art und Weise, wie die Produktion geplant wird, haben. Dieser Artikel zeigt Erkenntnisse aus einer simulationsbasierten Evaluierungsstudie von Methoden der Produktionsplanung und -steuerung in Bezug auf diese Herausforderungen. Basierend auf den gefundenen Erkenntnissen, wird ein Framework für eine optimale Konfiguration in der Produktionsplanung und -steuerung vorgestellt.

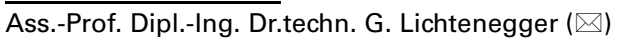
Institut für Maschinenbau- und Betriebsinformatik, Technische Universität Graz,

Kopernikusgasse 24/III,

$8010 \mathrm{Graz}$, Austria

E-Mail: gerald.lichtenegger@tugraz.at
Schlüsselwörter: Produktionsplanung,

Produktionssteuerung, Push-Systeme, Pull-Systeme, Ereignisorientierte Simulation, Industrie 4.0

\section{Introduction}

Today industry is dealing with challenges that have constantly arisen and intensified over the last twenty years a massive increase in product variety, a shortening of product life cycles, highly volatile demands [1]. Furthermore, Industry 4.0 with its enabling technologies often referred to as the Internet of Things (IoT) and Cyber-Physical Systems (CPS) is going to change the domain of production in a sustained manner. Needless to say that in this situation strongly linked functions like production planning and production control (PPC) have to be adapted and enhanced for their part. But the above mentioned newly offered possibilities especially in information technology also offer new promising opportunities - dramatically increased data quality, constant status updates from the shop floor, and the tracking of activities and objects in real time [2]. With that said, the need for a review and an evaluation of existing planning and control strategies as well as of configurations in production is evident. Therefore a detailed understanding of the production relationships and the existing concepts and methods of production planning and control is needed.

In this paper a simulation model-based approach is presented that enables a performance evaluation of a variety of PPC concepts applied under different production settings (see Fig. 1). One of the advantages of using a simulationbased approach is the possibility to even address production settings and strategies perhaps not used at the moment for different reasons and investigate their potentials for future application. The great challenge in production planning and control which can be seen as the process of determining the best economic use of the available production factors to fulfill the customer orders is to set improvements 


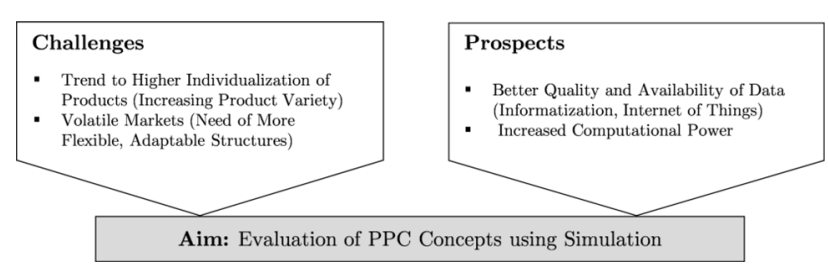

Fig. 1: Motivations for the evaluation

in many different target dimensions at the same time. This means one has to deal with contradictory objectives all the time. As an example Gutenberg describes the conflict between the utilization of production resources, the inventory and delivery reliability as the dilemma of scheduling [3]. This phenomenon lead to the development of hundreds of different planning strategies and methods such as lean concepts (e.g. JIT), material requirements planning (MRP), or even complex linear programming optimization approaches.

\section{Simulation-based Evaluation Study}

The goal of the presented evaluation study is to analyze various PPC methods with respect to their flexibility (ability) to respond to external changes and the impacts of the informatization in manufacturing. Based on different hierarchical types of flexibility, the product flexibility and the volume flexibility of Sethi \& Sethi [4] and respectively the mix flexibility and volume flexibility of Koste \& Malhotra [5] were identified as the major sources of flexibility that are associated with production planning activities. The impacts of informatization are modeled with different availabilities and qualities (deviations) of the transactional data needed for planning. Furthermore, the investigation is taking variability and lead time effects into consideration. Tab. 1 gives an overview of the different evaluation dimensions analyzed in the study. The data sets used in the evaluation study were captured during several industrial projects and represent different practical scenarios.

The general structure of the evaluation model consists of three main parts (see Fig. 2):

- Manufacturing model

- Customer model

- Methods of production planning \& control

\begin{tabular}{|c|c|c|}
\hline \multicolumn{3}{|c|}{$\begin{array}{l}\text { TABLE 1: } \\
\text { Evaluation dimensions of the simulation study }\end{array}$} \\
\hline Type & $\begin{array}{l}\text { Characteristic } \\
\text { Internal (Supply) }\end{array}$ & $\begin{array}{l}\text { External (De- } \\
\text { mand) }\end{array}$ \\
\hline $\begin{array}{l}\text { Flexibility } \\
\text { \& Variability }\end{array}$ & $\begin{array}{l}\text { Setup time } \\
\text { Supply variability } \\
\text { (MTTR) }\end{array}$ & $\begin{array}{l}\text { Part variety } \\
\text { Demand mix }\end{array}$ \\
\hline $\begin{array}{l}\text { Data Quality } \\
\text { \& Availability }\end{array}$ & $\begin{array}{l}\text { Inventory devia- } \\
\text { tion } \\
\text { Planning cycle }\end{array}$ & $\begin{array}{l}\text { Forecast changes } \\
\text { Forecast update } \\
\text { frequency }\end{array}$ \\
\hline Others & Lead time & \\
\hline
\end{tabular}

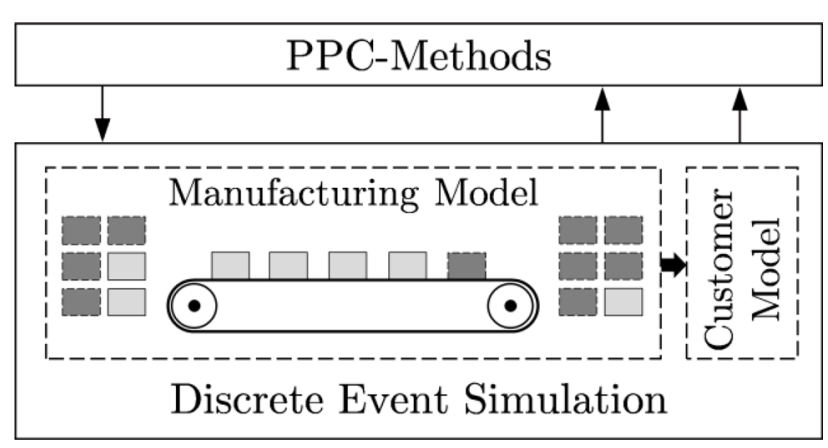

Fig. 2: General structure of the evaluation model

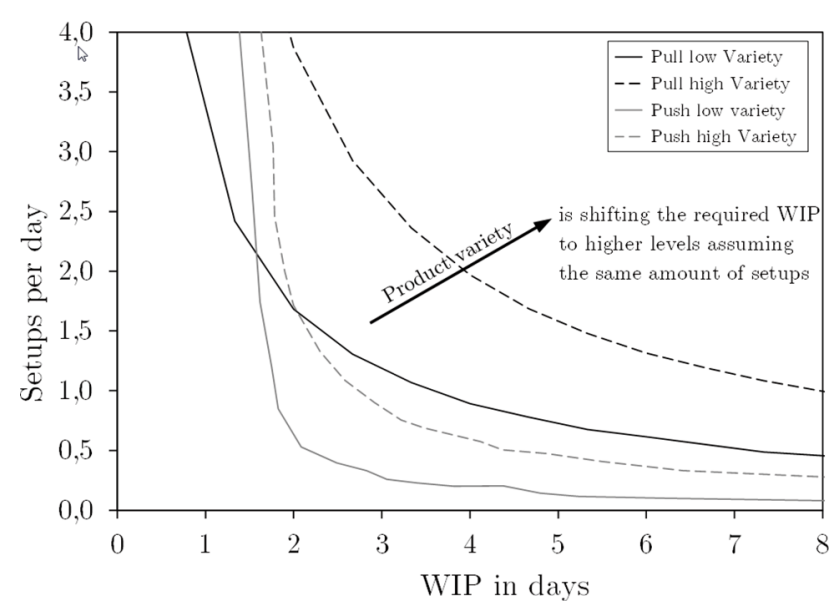

Fig. 3: Selected results of the simulation study (based on [6])

In the show case, the manufacturing model represents a flow-shop production with disconnected flow lines and the customer model is based on the logistic principles of automotive supply industry. These two model components are implemented in a discrete event simulation-type model (DES). In addition, the evaluation model contains various PPC methods which are either linked via programming interfaces to the DES or directly implemented in the simulation program.

With this model various standard parameter scenarios are analyzed over a simulation time of several days depending on the problem. The scenarios include evaluations of the impact of forecast changes, data availability, data quality, demand variability, and supply variability ${ }^{1}$. Representing the different analyzed scenarios, Fig. 3 shows selected results of the simulation study in required setups over work in progress (WIP) plots.

This chart shows the high influence of the product variety on the required number of setups. While, with a low external variability, the difference between the pull-type PPC system (e.g. Kanban) and the push-type system (e.g. MRP) is only minor (solid lines) at a high external variability, the push type system can demonstrate its superiority (dotted lines).

1 A more detailed explanation of the simulation model, the scenarios, and the results can befound in $[6,8]$. 


\section{Findings}

The research using the simulation-based evaluation study showed to be a valuable approach to better understand the influencing factors in PPC. A brief description of the findings with respect to the following domains will be given [6]:

- PPC model accuracy

- Data availability

- Data quality

- Product flexibility

Models are always only a limited representation of reality. In the process of model building, delimitation, reduction, decomposition, aggregation, and abstraction are used to capture the major elements and influencing factors of the complex reality. Several different PPC models with different accuracies regarding their representation of time, the used mechanisms for lot sizing, the capacity consideration etc. exist. The simulations showed that data availability and PPC modeling accuracy are related to each other. Furthermore, the ongoing informatization will dramatically increase data availability on the shop floor and in the supply chains. In PPC, mainly the inventory and demand data availability will be influenced. The prior insight regarding the PPC model accuracy already pointed out that this availability increase must go hand in hand with more detailed planning models. Otherwise no significant efficiency benefit can be achieved from this trend. The evaluation study, moreover, showed that real time availability of data is only partly necessary, especially when only a part of the data (e.g. inventory data) is available in real time, while other data which is relevant for planning (e.g. demand data) is only updated every day. In such a case, no real performance gain was measured in the simulation results. Apart from the availability of data, the quality of the data, measured in the evaluation by the inventory inaccuracy, will also increase through the informatization. Deviations between the data in information systems and the real inventories on the shop floor have to be buffered using additional safety inventory. The simulations using different inventory inaccuracies showed that in-detail PPC models are more sensitive to deviations in the stock levels than simple plan- ning models. This effect is mainly attributable to the already higher inventory levels of the simple PPC models in comparison with the more sophisticated models which can run with the same settings at a lower stock level. Consequentially, in-detail PPC models need more safety inventory to protect against the inventory inaccuracies than simple models. Apart from the aspects of informatization, also the product flexibility demanded by the customer is a major concern in PPC. The evaluations showed that the range of products has a high influence on the performance of the planning system. Especially the Kanban system showed only limited applicability when high product flexibility is needed. Only with a range of two different products, the Kanban system delivered a performance which was close to the performance of more advanced MRP systems.

\section{Configuration Framework for Production Planning and Control}

The selection of an optimal PPC configuration is a difficult task which depends on several factors and needs to be taken more and more frequently, especially in the rapidly changing economic environment. An interesting approach for the selection of the right PPC strategy can be found in the information/control/buffer (I/C/B) portfolio by Schwarz [7]. This framework analyzes different PPC strategies in the dimensions information system, control system, and buffer system. According to Schwarz [7], an operation must select the PPC strategy based on the total costs of these three components. His framework provides an elegant solution for the PPC configuration problem by combining the different dimensions on the common measure costs. However, the evaluation study showed that the I/C/B portfolio needs to be updated in some of the dimensions to fulfill present needs. The main drawback of the I/C/B framework is the missing consideration of the requisite flexibility of the manufacturing system based on the customer requirements. The simulations showed that the product flexibility has a major impact on the performance of a PPC system. Furthermore, the evaluation study showed a relationship between data availability and PPC model accuracy. Based on that, the $\mathrm{I} / \mathrm{C} / \mathrm{B}$ decision framework was adapted and extended (see Fig. 4).

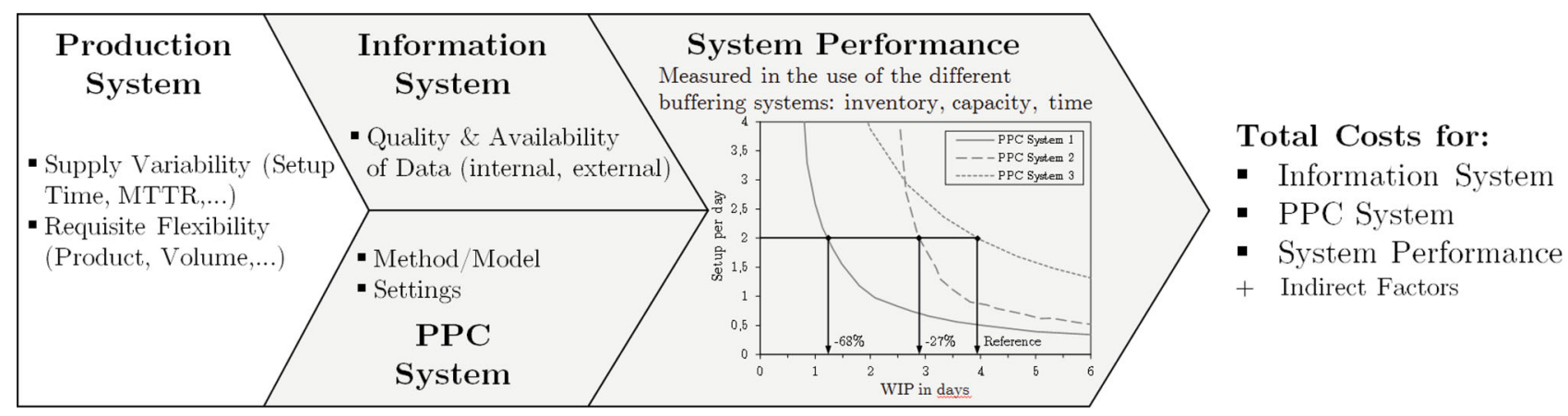

Fig. 4: Suggested PPC configuration best practice approach (based on [6] 
The new framework presented in Fig. 4 is grounded on three basic systems: the production system, the information system, and the PPC system. Furthermore, indirect factors that cover e.g. knowledge impacts are introduced additionally. The system performance results out of the design and the interactions between these factors.

The production system is mainly characterized by its supply variability and the requisite flexibility. The supply variability includes effects originating from set-up activities, breakdowns, and quality defects. The requisite flexibility originates from the customer requirements in terms of product variations and delivery time expectations. The evaluation study shows that the aforementioned factors have a major impact on the overall performance of all PPC approaches. Despite the best practices in PPC configuration, standard measures using lean tools and complexity management approaches have to be taken to gain control over these highly influencing factors. The joint configuration of the information system and the PPC system is the major challenge in the selection process. Due to the interaction between the information system and the PPC system that was shown in the evaluation study, an approach different to the I/C/B portfolio was followed (joint consideration of the two systems). The quality and availability of external (customer) and internal (supply) data have remarkable influences on the selection of a fitting PPC model. Next to the direct factors of the production, information and PPC system, indirect factors also have an influence on the systems performance. These indirect factors can be mainly attributed to the required skill and knowledge level for the different PPC methods. Especially pull-type PPC systems require a certain discipline and responsibility on the shop floor to operate properly. Overall it can be said that these factors result in a performance of the system with a certain use of the different buffering systems (inventory, capacity, and time) to match the demand. As the evaluation study showed, simulation is a key technique to reveal the performance. The decision on the optimal PPC configuration should be based on the overall system costs for the information system, the PPC system, the resulting system performance and the costs for the indirect factors [6].
As a consequence of the previously described facts and circumstances, simple planning methods could surprisingly return a solution at the overall cost optimum when inventory keeping is cheap. That does not necessarily mean that an investment in PPC systems using in-detail models and high quality data are not worth the effort amongst others it strongly depends on the cost factors. To conclude, this generally means that an enterprise has to first calculate the potential benefits and the return of an investment in the informatization of the production and then set up an aligned and cost optimal configuration for its operations.

Open Access This article is distributed under the terms of the Creative Commons Attribution 4.0 International License (http://creativecommons.org/licenses/by/4.0/), which permits unrestricted use, distribution, and reproduction in any medium, provided you give appropriate credit to the original author(s) and the source, provide a link to the Creative Commons license, and indicate if changes were made.

\section{References}

1. Nyhuis, P.; Reinhart, G.; Abele, E.: Wandlungsfähige Produktionssysteme, Hannover: TEWISS, 2008

2. Bauernhansl, T.: Die Vierte Industrielle Revolution: Der Weg in ein wertschaffendes Produktionsparadigma, in: Bauernhansl, T.; Hompel, M.; Vogel-Heuser, B. (Eds.): Industrie 4.0 in Produktion, Automatisierung und Logistik, Wiesbaden: Springer, 2014, pp 5-35

3. Gutenberg, E.: Grundlagen der Betriebswirtschaftslehre. Band 1: Die Produktion, Berlin: Springer, 1951

4. Sethi, A. K.; Sethi, S. P.: Flexibilty in Manufacturing: A Survey, International Journal of Flexible Manufacturing Systems, 2 (1990), No 4, pp 289-328

5. Koste, L. L.; Malhotra, M. K.: A theoretical Framework for analyzing the Dimensions of Manufacturing Flexibility, Journal of Operations Management, 18 (1999), no. 1, pp 75-93

6. Wolfsgruber, C.: Informatization in Production Planning and Control: A Simulation based Evaluation of the Impacts in Flow-Shop Production Systems, Doctoral Thesis, Graz, University of Technology, 2016

7. Schwarz, L. B.: A New Teaching Paradim: The Information/Control/ Buffer Portfolio, Production and Operations Management, (1998), no. 2, pp 125-131

8. Wolfsgruber, C.; Vössner, S.: Informatisierung in der Produktionsplanung und -steuerung: Eine simulationsbasierte Analyse der Auswirkungen am Beispiel der Fließfertigung, Leoben, 2015 